\title{
Rasmussen's aneurysm in a child with acute lymphoblastic leukaemia
}

\author{
Sanjeev Khera (D) , ${ }^{1}$ Ashish Kumar Simalti, ${ }^{2}$ Dhanalakshmi Balasubramaniam, ${ }^{3}$ \\ Nikhil Tiwari ${ }^{4}$
}

${ }^{1}$ Department of Pediatrics, Army Hospital Research and Referral, New Delhi, Delhi, India ${ }^{2}$ Department of Pediatrics, Military Hospital, Dehradun, India

${ }^{3}$ Department of Radiology, Army Hospital Research and Referral, New Delhi, Delhi, India ${ }^{4}$ Department of CTVS, Army Hospital Research and Referral, New Delhi, Delhi, India

Correspondence to Dr Sanjeev Khera; kherakherakhera@gmail.com

Accepted 12 June 2020

\section{DESCRIPTION}

A 6-year-old female child was diagnosed with B-lineage acute lymphoblastic leukaemia and was started on intermediate risk Berlin-Frankfurt-Münster 2002 chemotherapy protocol. During week 3 of induction chemotherapy (oral prednisolone, parenteral vincristine, daunorubicin and L-asparaginase), she developed febrile neutropenia (FN). Her chest $\mathrm{X}$-ray revealed non-homogenous opacity in right middle zone. Her blood cultures were negative and serum galactomannan was normal. She was given antibiotics and antifungals as per $\mathrm{FN}$ protocol (meropenem, vancomycin and amphotericin). She continued to be symptomatic with persistent lung opacity and was worked up and managed as nonresolving pneumonia. Contrast-enhanced CT scan of the chest was suggestive of consolidation and surrounding ground glass haze within posterior segment of right lower lobe along with a cavitary lesion measuring $8.9 \times 13 \mathrm{~mm}$ with surrounding air crescent all around. Work up for tuberculosis (TB): Mantoux test, gastric aspirate for acid-fast bacilli (AFB) and GeneXpert test were negative. Bronchoalveolar lavage was not done due to associated severe thrombocytopenia.

In the third week of illness, she had bouts of massive haemoptysis. A pulmonary CT angiography revealed a well-defined fusi-saccular aneurysm measuring $11 \times 14 \times 15.6 \mathrm{~mm}$ seen at the bifurcation of right descending pulmonary artery near right hilum of lung in the vicinity of cavitary lesion with no extravasation of contrast or intraluminal thrombus (figures 1 and 2). Child was planned for coil embolisation of aneurysm but had peroperative aneurysmal rupture and was

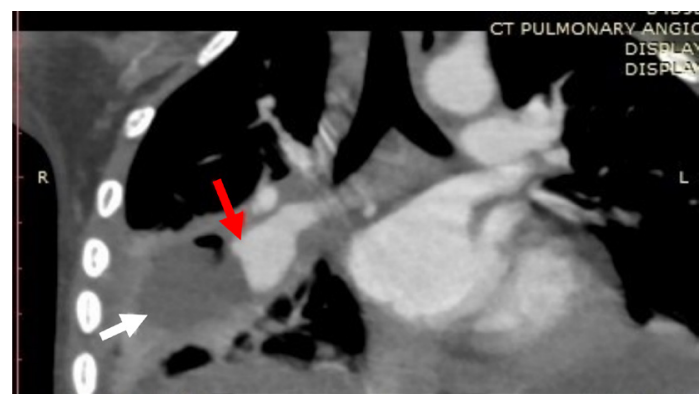

Figure 1 Coronal view of CT angiography of the chest showing consolidation in posterior segment of right lower lobe along with a cavitary lesion (white arrow) with surrounding air crescent all around and adjacent welldefined Rasmussen's aneurysm at the bifurcation of right descending pulmonary artery (red arrow).

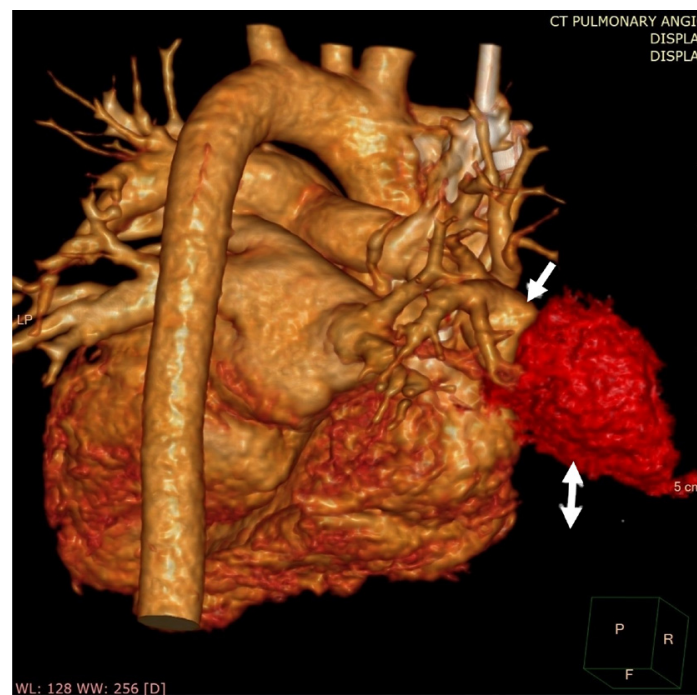

Figure 2 A virtually rendered pulmonary CT angiography image showing a well-defined fusi-saccular Rasmussen's aneurysm at the bifurcation of right descending pulmonary artery (single white arrow) and adjacent cavity (double white arrow).

managed by resection of descending branch of pulmonary artery along with lobectomy of middle and lower lobe of right lung . Postoperative period was devoid of any complications. The resected pathological specimen did reveal AFB and granulomatous lesion. She was started on antitubercular therapy (ATT) as per Revised National TB Control Programme guidelines. Meanwhile, her mother was investigated for contact and found to have

\section{Patient's parent perspective}

My daughter was diagnosed with blood cancer. She was started on chemotherapy but she developed a pneumonia, which was being managed with antibiotics. While on treatment, she had sudden bouts of bleeding with cough and after investigations required emergent surgery. After surgery, she recovered well. My wife also had cough and weight loss during the hospital admission of my daughter. She did not seek medical attention earlier since she was preoccupied with my daughter. However, once my wife was investigated, she was diagnosed with tuberculosis. I was told that the pneumonia in my daughter is because of tuberculosis. Both of them were started on antitubercular therapy and are doing well. 


\section{Learning points}

- Rasmussen's aneurysm is a rare form of mycotic aneurysm caused by weakening of the pulmonary artery wall from adjacent cavitary tuberculosis.

- Rasmussen's aneurysm should be kept in differential diagnosis when a patient with cavitary pneumonia presents with massive haemoptysis.

- CT angiography is the diagnostic modality of choice for Rasmussen's aneurysm.

sputum positive pulmonary TB. The minimal residual disease to look for leukaemia status in view of prolonged interruption of chemotherapy was $<0.01 \%$, suggesting remission status of leukaemia. She was continued on intensive chemotherapy along with ATT post recovery and tolerated it well. Presently, she is in maintenance phase of chemotherapy and has completed ATT for 6 months.

Rasmussen's aneurysm is a rare mycotic aneurysm caused by weakening of the pulmonary artery wall from adjacent cavitary TB. It is very rare in children and has never been described with haematological malignancies. Progressive weakening of the arterial wall occurs as granulation tissue replaces both the adventitia and the media. The granulation tissue in the vessel wall is then gradually replaced by fibrin, resulting in thinning of the arterial wall, pseudoaneurysm formation and subsequent rupture. Haemoptysis is the usual presenting symptom and may be life-threatening. Coil embolisation remains the management modality of choice. ${ }^{1}$

Contributors SK conceptualised, written manuscript and have contributed to diagnosis and management of the case. AKS, DB and NT have contributed to diagnosis and management of the case.

Funding The authors have not declared a specific grant for this research from any funding agency in the public, commercial or not-for-profit sectors.

Competing interests None declared.

Patient consent for publication Parental/guardian consent obtained.

Provenance and peer review Not commissioned; externally peer reviewed.

ORCID iD

Sanjeev Khera http://orcid.org/0000-0003-4754-8340

\section{REFERENCE}

1 Sapra R, Sharma G, Minz AK. Rasmussen's aneurysm: a rare and forgotten cause of hemoptysis. Indian Heart J 2015;67 Suppl 3:S53-6.

Copyright 2020 BMJ Publishing Group. All rights reserved. For permission to reuse any of this content visit

https://www.bmj.com/company/products-services/rights-and-licensing/permissions/

BMJ Case Report Fellows may re-use this article for personal use and teaching without any further permission.

Become a Fellow of BMJ Case Reports today and you can:

- Submit as many cases as you like

- Enjoy fast sympathetic peer review and rapid publication of accepted articles

- Access all the published articles

- Re-use any of the published material for personal use and teaching without further permission

\section{Customer Service}

If you have any further queries about your subscription, please contact our customer services team on +44 (0) 2071111105 or via email at support@bmj.com.

Visit casereports.bmj.com for more articles like this and to become a Fellow 